\title{
BUY AND SELLING IN THE PERSPECTIVE OF JAHILIYAH AND ISLAM A COMPARISON STUDY A REVIEW OF SHARIA ECONOMIC HISTORY
}

\author{
Ahdi \\ IAILM Suryalaya Tasikmalaya Indonesia \\ Email: ahdinurudin333@gmail.com \\ Hamdan Firmansyah \\ Sunan Gunung Djati State Islamic University, Bandung Indonesia \\ Email: abihilqi@gmail.com
}

\begin{abstract}
Buying and selling or trading in the term fiqh are called al-Ba'i which, according to etymology, means selling or replacing. The word al-Ba'i in Arabic is sometimes used for the understanding of his opponent, namely the word al-Syira (buy). Thus, the word al-Ba'i means selling, but also means buying. In terminology, buying and selling is an agreement to exchange objects or goods that have a good value between the two parties, one receives objects and the other receives them in accordance with an agreement or provision that has been justified and agreed upon. In the Qur'an, there are many statements that describe the life of the Arabs, including trade problems. Islam is very concerned about the problem of trade in this Arab nation by setting for them what they need. Many of the Prophet's hadith mention the legal issues of buying and selling, monopoly, accounts payable, profits, etc. Jahiliyah Arabs have a market as a center of trade. Usury is one type of economic transaction that is actually carried out and developed in Arab society. In Islam, buying and selling if it contains usury, illicit goods, reduces scales, and by force.
\end{abstract}

Keywords: Buying and selling, Jahiliyah, Islam

\section{A. INTRODUCTION}

In the Al-qura'n there are many descriptions that describe the life of the Arabs, including trade issues which are often used as parables (Depag, 1984). For example, Surah Fathir verse 29:

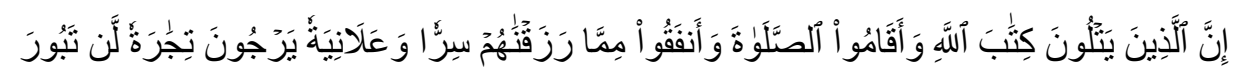

Meaning: "Surely those who always read the book of Allah and offer prayers and spend a part of the sustenance that We give them secretly and openly, they hope for a business that will not lose money"

Furthermore, the Word of Allah in Surat Al-Baqarah verse 16:

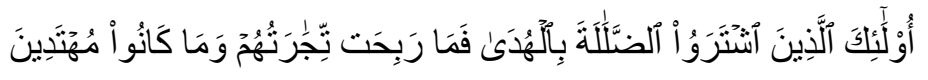

Meaning: "They are the ones who buy error with guidance, so they are not lucky in their trade and they do not get a clue"

And the words trade (tijarah), profit (ribh), loss (khusran) often appear in the vocabulary of the Koran. And this is enough to prove that trade is something inherent in the life of the Arab nation.

We may wonder: "trading is an activity that requires reading and calculation. Then how can the Arabs who are said to be ummiy (literate) do this? The answer is that this illiteracy assessment applies to the Arabs as a nation in general, not as units. There are Arabs who are good at $\mathrm{Ca}$ LisTung. The Quraish people, for example, had long learned to write in Herah and Anbar, as did the Taef people. 
In fact we find in the Al-quran in the part of the letter Al-baqarah verse 282 a statement that the Arabs are familiar with Ca LisTung in their trading activities..

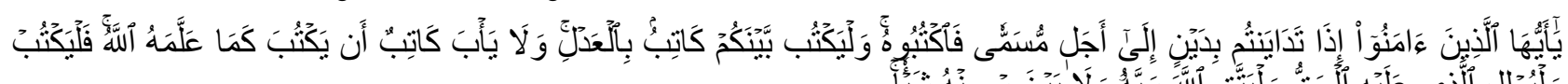

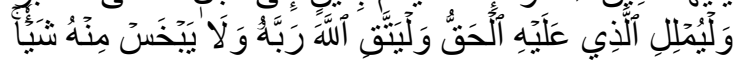

Meaning: "O you who believe, if you are not in cash for a specified time, you should write it down. And let a writer among you write correctly. And don't the writers be reluctant to write it down as Allah taught it, they let him write, and let the person in debt imitate (what is to be written), and let him fear Allah his God, and let him not reduce anything less than his debt "

In the Al-quran Surat At-Taubah verse 28 there are signs that indicate a historical break in the trading life of Mecca. It happened when the verse came down:

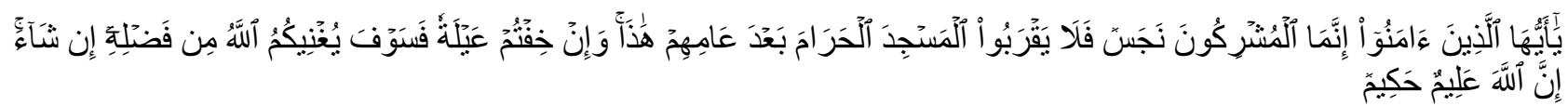

It means: "O you who believe, verily those who are polytheists are unclean, so they should not approach Masjid al-Haram after this year. And if you are worried that you will be poor, then Allah will later give you wealth from His grace, if He wills. Verily Allah is All-knowing, Most Wise "

When polytheists were forbidden to enter Mecca in the year $9 \mathrm{AH}$, there was a fear among the people that poverty would occur due to the interruption of trade between Muslims and polytheists during the Haij seasons. So then Allah promised wealth to them not through trade routes. Instead, as mentioned by the commentators, is spoils of war and conquest (futuh) in the near future.

In this way, the trading conditions of the Arabs entered a new phase. And Islam is very concerned about the trade problems of the Arabs by assigning them what they need. Many of the Prophet's hadiths allude to legal issues of buying and selling, monopoly, accounts payable, profit, etc. The caliphs after the Prophet were very concerned about trade issues after the problems associated with the opening of the territory (futuhat) were completed during the time of Abu Bakr, Umar and Uthman. We need to note that during the futuh period, the trade problem did not stop, even the caliph's employees were busy doing trading business. This is sufficient proof for us that the Arabs are very concerned about trade, which is their profession.

Umar was very strict with his employees not to do trading business. In fact, he would punish his employees who were busy in the trade and were totally unwilling to accept any excuses regarding this matter. Umar said: "I sent you as employees and not as merchants." Historians agree that the first three caliphs were merchants.

Abu Bakr and Uthman were traders. Meanwhile, Umar, during the period of ignorance, was a trader in Gaza, while Ali, we do not know that he was doing a trading business. When Islam emerged, Ali was still a child. But he certainly knows about trade and its ins and outs because this trade is a profession of the surrounding community. When Ali was caliph he understood the importance of this trade issue.

\section{B. METHOD}

The method used in this research is the comparative method (comparative method), which is a method that uses a minimum of two or more cases (Nawawi \& Zayadi, 1994), by looking for similarities and differences between each and looking for answers fundamentally about the cause and effect by analyzing the factors that cause the phenomenon, as a basis for comparison The method used in this study is a comparative method, namely a method that uses a minimum of two or more cases, by looking for the relationship between the 
similarities and differences between each and looking for answers fundamentally about the causes. consequently by analyzing the factors that cause the phenomenon to occur, as a basis for that comparison.

\section{RESULT AND DISCUSSION}

a. Buy and sell

1. Definition of Buying and Selling

Buying and selling or trading in figh terms is called al-ba'i which according to etymology means selling or replacing. Wahbah al-Zuhaily defines in language by exchanging something for something else. The word alBa'i in Arabic is sometimes used to mean the opposite, namely the word al-Syira (buy). Thus, the word al-ba'i means to sell, but kalius also means to buy (Zulhaily, 2005).

In terminology, there are several definitions of buying and selling, each of which is the same definition. Some other scholars gave the understanding:

a) Ulama Sayyid Sabiq: He defines that buying and selling is the exchange of property for property on the basis of giving up or transferring property in a justifiable compensation. In this definition property, replaceable and can be justified. What is meant by assets in the definition above is everything that is owned and useful, then except those that are not owned and are not useful. What is meant by compensation is so that it can be distinguished from a grant (giving), while what is meant is justified (ma'dzun fih) so that it can be distinguished from prohibited buying and selling.

b) Hanafiyah Ulama: He defines that buying and selling is the exchange of property with other assets in a special way. The meaning of hanafiyah ulama by these words is through the consent of the qabul, or it is also permissible to share goods and prices from the seller and the buyer.

c) Ulama Ibn Qudamah: According to him, buying and selling is the exchange of property for assets in the form of transfer of ownership and ownership. In this definition, the words ownership and ownership are emphasized, because there is also an exchange of assets that are not necessarily owned, such as leasing.

From some of the above definitions it can be understood that buying and selling is an agreement to exchange objects or goods that have a happy value between the two parties, one receives the objects and the other receives them in accordance with the agreement or provisions that have been justified by syara 'and agreed upon.

\section{The Legal Basis of Buying and Selling}

Buying and selling as a means of helping fellow human beings has a strong foundation in al-quran (Departemen Agama Republik Indonesia, 1984), among others: Allah says in Surat Al-Baqarah verse 275:

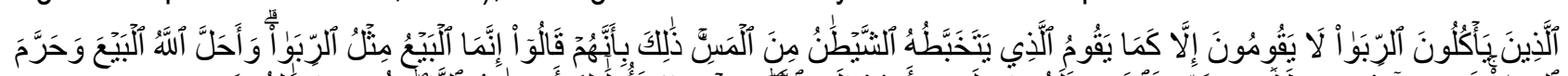

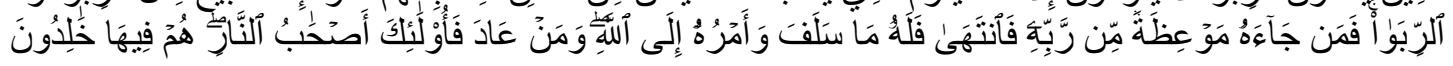

Meaning: People who eat (take) usury cannot stand but are like the founding of people who are possessed by shit because (pressure) of insanity. Their condition is because they say (argue), In fact buying and selling is the same as usury, even though Allah has made buying and selling legal and forbidden usury. people who have come to him the prohibition of his Lord, then continue to stop (from taking usury), So for him what he had taken first (before the prohibition came); and matters (up to) to Allah. people who return (take usury), Then that person is the inhabitants of hell; they are eternal in it.

Allah says in Surah Al-Baqarah verse 198:

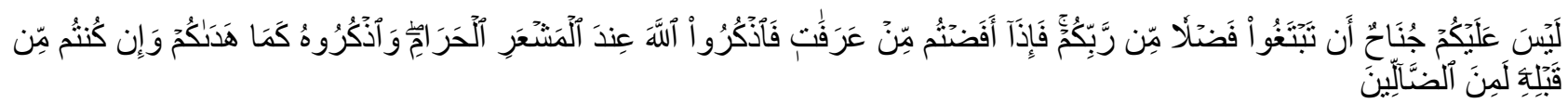


Meaning: there is no sin for you to seek a gift (sustenance from commerce) from your Lord. So when you have departed from 'Arafat, pray to Allah in Masy'arilharam. and dhikr (by chanting) Allah as He shows you; and Behold, you before that really Including people who are perverted.

Allah says in the Al-quran Surat Aln-Nisa 'verse 29:

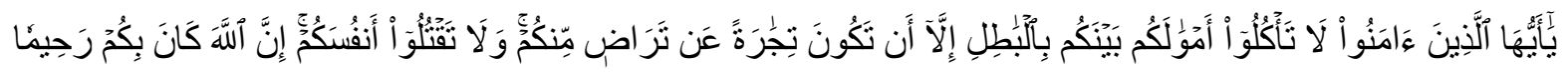

Artinya: Hai orang-orang yang beriman, janganlah kamu saling memakan harta sesamamu dengan jalan that is vanity, except by way of commerce that applies consensually among you. and do not kill yourselves; Indeed, Allah is Most Merciful to you.

There are several traditions of the Prophet Muhammad, which talk about buying and selling (al-Syathibi, 1975), including:

Hadith narrated by Rifa'ah ibn Rafi ': "Rasulullah saw, was asked by one of his friends about what job was the best. Rasulullah Sawa, answered the efforts of human hands themselves and every blessed buying and selling (H.R Al-Bazzar and Al-Hakim).

The hadiths of al-Baihaqi, ibn majah and ibn hibban, the Messenger of Allah stated: "Buying and selling is based on consensuality"

The hadith narrated by al-Tirmizi, Rasulullah said: "An honest and trusted merchant is equal (his place in heaven) with the prophets, sadiqqin, and martyr".

\section{Buying and Selling Law}

Buying and selling is unlawful if it does not meet the requirements or is in harmony with buying and selling or is prohibiting buying and selling. Buying and selling in general is permissible. Buying and selling becomes mandatory depending on certain situations and conditions.

The scholars of figh say that the law of origin of buying and selling is permissible. However, in certain situations, according to Imam al-Syathibi (d. $790 \mathrm{~h}$ ), the Maliki fiqh expert, the law may turn out to be mandatory. Imam alSyathibi gave an example when there was the practice of intikar (hoarding of goods so that stocks were lost from the market and prices soared up). If someone does intikar and it causes an increase in the price of the hoarded and stored goods, then according to him, the government may force the merchant to sell the goods according to the price before the price hike occurred. In this case, according to him, the merchant is obliged to sell his goods in accordance with government regulations. This is the same principle as al-Syathibi, that if it is permissible, if it is completely abandoned, then the law may become mandatory. If a group of big traders does a boycott not to sell rice anymore, the government can force them to trade rice and these traders are obliged to do so. Likewise in other conditions (Suhendi, 2002).

\section{Rukun Buy and Sell}

In determining the terms of sale and purchase, there are differences of opinion between the Hanafiyah scholars and the number of scholars. According to the Hanafiyah ulama, there is only one pillar of sale and purchase, namely the consent of the qabul, the consent is an expression of buying from the buyer, and qabul is an expression of selling from the seller. According to them, what becomes harmonious in buying and selling is only the willingness (pleasure) of both parties to conduct a sale and purchase transaction (Nasrun, 2007). 
However, the jumhur of scholars states that there are four pillars of buying and selling, namely: there are people who have contract (seller and buyer), there is sighat (lafal ijab qabul), there are items that are bought (ma'qud alaih) and there is an exchange rate for goods substitutes.

\section{Terms of Sale and Purchase}

The terms of sale and purchase are as follows:

a) Requirements for a person with a contract: sensible, on a consensual basis and the person performing the contract is a different person, meaning that a person cannot act simultaneously as both a seller and a buyer.

b) Requirements related to consent qabul: the person who pronounces it is mature and sensible, qabul is in accordance with consent and consent and qabul is carried out in one assembly.

c) The conditions for the goods being traded are: holy, the goods being traded are their own property or given the power of someone else who owns them, the goods being traded have benefits, the goods being traded are clear and can be controlled, the goods being traded can be known for their level, type, nature, and the price and may be submitted during the contract (Djunaedi, 2008).

d) Terms of exchange rate (price of goods): the price agreed upon by both parties must be clear in amount, may be submitted at the time of the contract, if the price of the goods is paid later (owed) then the payment must be clear and if the sale and purchase is carried out by mutual exchange goods, goods that are used as exchange rates are not goods that are prohibited by syara ', such as pigs and khamar, because these two types of objects have no value according to syara' (Ihsan, 2008).

\section{Prohibited Buying and Selling}

a) Bai Najsy: Najsy literally means to influence (raise). Meanwhile, according to the meaning of terminology, najsy means if someone increases the price of an item, but does not intend to buy it, but only to make other people interested in the item so that he is trapped in it, or he praises the commodity with advantages that the commodity does not actually have. these for the sole purpose of promotion. Rasulullah SAW said, It means: "From Ibn Umar, he said," Rasulullah forbids najsy " (Zulhaily, 1999).

b) Bai Ihktikar: Ihtikar comes from the word hakara which means az-zulm (persecution) and isa 'al-mu'asyarah (destroying relationships). The term means storing merchandise to wait for price hikes (Hasan, 2004). Rasulullah SAW said, it means: " Whoever destroys the market price, so that the price increases sharply, then Allah will place him in hellfire on the Day of Resurrection. "

c) Ghisyhy: Ghisysy is a way of hiding defective items or by displaying good items and tucking in between bad items. Rasulullah Saw said, it means: "Whoever deceives us, then he is not included in our group"

d) Habalul Habalah: From Ibn Umar ra, he said, "It was the ignorant people who used to sell and buy camel meat until the birth of the womb, then the camel that was born was pregnant. And habalul habalah, namely the camel that was conceived was born, then the camel that was born was born. pregnant, then the Prophet forbade such a thing."

e) Bai 'Al-Ma'dum: bai' al ma'dum, namely buying and selling goods which are not available at the place of transaction. Ba'i al ma'dum is a form of buying and selling that is haram on the grounds that there is an argument against buying and selling gharar or buying and selling that contains an element of fraud.

f) Bai 'Al-Gharar (Buying and Selling by Gharar): gharar contains certain characteristics such as risk, danger, speculation, uncertain results, and unknown future profits (Mansoori, 2010). Or it can be said that buying and selling is gharar (which is not clear in nature), namely all forms of buying and selling which contain jahalah (unclear element), or in it there is an element of betting or gambling. Rasulullah Saw said, "It was 
narrated from Abu Hurairah that the Prophet prohibited the sale and purchase of Hashah (buying and selling of land which determines its size as far as a stone's throw) and also prohibited buying and selling of Gharar"

g) Bai Mulamasah: buying and selling that occurs when you touch an item you have to buy.

h) Bai al-Madhamin: (conceived), namely buying and selling that is contained by a female parent animal that is still a fetus.

i) Bai Munabadzah: that is, the seller and the buyer throw their clothes at each other without looking, they both say this with this.

j) Bai al-Hashah: that is, the seller or buyer throws stones, such as clothes that hit the stone that are sold or bought, without being seen and chosen.

k) Bai al-Malaqih: namely buying and selling that is on the backbone of male animals.

I) Bai 'Asb al-Fahl: namely buying and selling by marrying males, both horses, camels and goats and others. Taking the reward of marrying an animal is haram, there is gharar in it, it is not known and whether it is capable of giving up, the female can get pregnant or not.

m) Bai Majhul: (unknown), be it goods, size, price, time and things that cannot be delivered, such as fish still in the sea, or birds still in the air.

n) Bai Tsunya: namely buying and selling that is exempt from the unknown. Such as buying and selling food or clothing and partially excluded without any details. Buying and selling is vanity and is not allowed, because it contains jahalah and gharar and eats other people's property with vanity. However, if what is excluded is known, then the sale and purchase is legal, such as buying and selling trees and certain trees whose details are known are excluded.

o) Bai al-Inah: Buying and selling al-inah is a sale and purchase which is prohibited in Islam by the majority of scholars, because it is manipulated to do usury. Buying and selling al-inah is selling goods at a credit price and buying them again at a cash price.

p) Bai Muzabanah: that is, buying everything randomly without knowing the scale, measure and amount both in terms of the scale or the measure as well as the number either by prejudice or size.

q) Bai Shafqah (wholesale): namely buying and selling includes / combining the halal with the haram, the known and the unknown, the ones that are not owned, what is valid with the fasid and the good with the bad. Bai Muhaqalah: yaitu menjual buah yang masih pada tangkainya dengan buah yang sudah ditimbang baik secara prasangka maupun dengan ukuran seperti membeli gandum pada yang masih pada tangkainya dengan gandum yang sudah ditimbang. Ini adalah jual beli batil, karena ini riba, yaitu, menjual yang di timbang dengan timbangan yang sejenis secara tidak seimbang, menduga duga itu tidak boleh.

r) Bai Talaqqi al-Jalab or Rukban or al-Sil'a: That is, some people go out to intercept goods before they enter the market and before the owner of the goods knows the price, then they tell the owners that the price has fallen, and the goods are in a deserted market. / unsold they deceive him and buy the goods at a low price. Buying and selling is vanity and haram because it causes madarat and fraud to the owner of the goods.

s) Bai al-Hadir li Bad: Namely the broker goes out to meet the carrier and tells him to keep this to me so I can gradually sell it at a higher price then it popularizes people and becomes expensive for their needs. Buying and selling is vanity and haram because it causes harm to people.

\section{b. Buy and Sell History Review}

Arabs are divided into two regions, namely Arab bedouin (village) and hadhari (urban). From this, it appears the difference in their sources of livelihood. Bedouin Arabs depend on livestock for their livelihoods. They move around sending livestock to areas that are experiencing the rainy season or to pasture. They consume meat and milk from their livestock, make clothes, tents, and furniture from wool (sheep's hair) and sell it when their personal and family needs are met. Their wealth can be seen from the number of lives tock they have. 
As for urban Arabs, it is divided into two. People who live in fertile areas such as Yemen, Taif, Medina, Najd, Khaibar or others, they depend on agriculture for their source of life. Even so, the majority of them depend their livelihoods on commerce. Mainly the inhabitants of Mecca, they have a special business center. The inhabitants of Mecca have a separate position in the view of the Arabs, namely they are residents of the land of Haram (Mecca).

The transportation they relied on at that time was a camel, which was considered a desert boat. Camels are wonderful vehicles. Camels have strong strength, are able to withstand thirst and are able to travel very far. These camels go with merchandise from other countries, and then return with products from countries where they are traded.

This trading activity was also carried out by aristocrats such as: Hashim, Abu Talib, Abu Lahab, Abbas, Abu Sufyan bin Harb, Abu Bakr, Zubair bin Awwam, and others. Some of them sell their own merchandise and some sell other people's goods for wages or by sharing the results.

Allah Subhanahu wa Ta'ala perpetuated the trade trip of the Quraish people as a very famous trade trip, namely the winter trip to Yemen, and vice versa the summer trade trip to Syria. In the Al-quran Surat Quraish: 1-4 (Depag, 1984). Allah says:

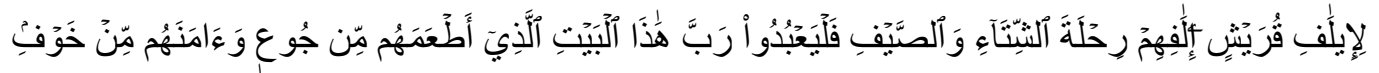

Meaning: "Because of the habits of the Quraish people, (ie) their habit of traveling in winter and summer. So let them worship the Rabb of this house owner (Ka'bah). Who gave them food to eliminate hunger and keep them safe from fear "

As a consequence of this flow of trade, the Arabs in the era of ignorance had markets as trading centers. Famous trade centers, namely: Ukazh, Mijannah, and Zul Majaz. Of these three markets, the largest and most visited is Ukazh. This market was visited by Arabs from various regions throughout Arabia. Most visitors come from Qabilah (tribe) Mudhar, because this market is located in their area.

This trade center is not only a place for trade transactions, but also a meeting center for literary experts, poets and orators. They gather to test each other. Thus, as the development of modern cities today, the market concept during the jahiliyah era was not only a shopping center, but also a center of civilization, rich languages and global transactions.

As a trading center, during the Jahiliyah era, usury transactions were evenly distributed in the Arabian Peninsula. It could be that they contracted this disease because of the influence of the Jews who justified usury transactions with non-Children of Israel. However, the unique thing about usury transactions during the Jahiliyah period, which was strictly prohibited during the Islamic period, turned out to be lighter than usury in circulation in modern times. The creditor said to the debtor, "You want to pay, or you give additional, and I will give an additional due (payment)". So, the money is borrowed a little, but must be returned in multiplied amounts. This very suffocating usury transaction was not only carried out by the lower classes, but also by the aristocracy. That was a cursory description of the economic conditions of the Arab Jahiliyah people.

When Islam came and became their religion, these bazaars were still running for a while, which were then abandoned. Likewise, Islam has come to abolish usury transactions, because usury only destroys the economic order of society. Islam sees the concept of buying and selling as a tool to make humans mature in thinking patterns and carrying out various activities, including economic activities. The market as a place for buying and 
selling activities must be used as a place for proper training for humans as caliphs on earth. So actually buying and selling in Islam is a place to produce strong caliphs on earth.

In the Al-quran Surat Al Baqarah: 275 (Departemen Agama Republik Indonesia, 1984), Allah affirms that:

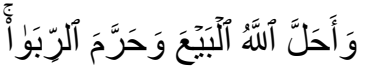

Meaning: "... Allah makes buying and selling legal and forbidding usury ...".

The interesting thing about this verse is the prohibition of usury which is preceded by the prohibition of buying and selling. Buying and selling (trade) is a basic form of human economic activity. We know that the market is created by transactions from buying and selling. A market can arise when there is a seller who offers goods or services for sale to buyers. From this simple concept, an economic activity was born which later developed into an economic system.

c. Comparative Study of Buying and Selling between Jahiliyah and Islam

Furthermore, from the historical review above, it can be obtained the aspects of buying and selling, namely the market, buying and selling behavior and money as a comparison material in this discussion.

1. Buying and Selling in Jahiliyah

a) Market

The Arabs of the ignorance era had markets as trading centers. This trade center was not only a place for trade transactions, but also a meeting center for literary experts, poets and orators. They gather to test each other. Thus, as the development of modern cities today, the concept of the market during the jahiliyah era was not only a shopping center, but also a center of civilization, rich languages and global transactions (Chamid, 2010).

b) Buying and Selling Behavior

In the pre-Islamic Arab era or what is often called the jahiliyah era, it was common to conduct transactions that smelled of usury. Ath-Tabari stated: "During the period of ignorance, the practice of usury was in the multiplication and excess of one year of age. For example, a person is in debt. when it is due, the creditor comes to collect it, saying, 'You will pay your debt or will you just give me the extra (interest)? If he has something he can pay for then he pays too. If not, then he will perfect it for the next one year. If the debt is in the form of ibnatu makhadh (one-year-old camel boy), then the payment will be ibnatu labun (two-year-old camel boy) in the second year. Then he will make it a hiqqah (a camel boy who is three years old), then make it a jadzah (adult camel). Furthermore, multiples of four and above. " Also in the case of gold or money debt, usury applies (Tarmizi, 2014).

\section{c) Money}

The Arab community at that time in using existing money, both gold dinars and silver dirhams, was based on the scales, not on the numbers, because these coins were not the same in weight. Or rather, they do not differentiate between (money) that has been printed (madhrub), that which has been stamped (masbuk) and what is still in the form of pellets (tibr). All of these forms they use as money on the basis that it is gold or silver, and do not require that they have been made in any special form as (official) money.

In carrying out transactions for Arabs during the Jihiliah period, several types of scales were used in addition to the Baghli Dirham and the Tabari Dirham; among others, Rithl (equal to 12 Uqiyah), Uqiyah (equal to 40 Dirhams), Nishsh or Nasysy (equal to half of Uqiyah, which is 20 Dirhams), Nuwah (equal to 5 Dirhams), Daniq (equal to one sixth Dirham or eight fifth of a grain (habbah) moderate sya'ir peanuts, Qirath (equal to half a Daniq), and Habbah (weighing one medium sya'ir bean). 
2. Buying and selling in Islam

a) Market

The market is guaranteed freedom in Islam. The free market determines the methods of production and prices, there should be no disturbances that result in the disturbance of the market balance. The market as a means of distribution serves to facilitate the process of distributing goods or services from producers to consumers. With the existence of a market, producers can relate either directly or indirectly to offer their products to consumers. The market is a meeting place between sellers and buyers. In this market the seller offers goods or services to the buyer. Buyers who need goods or services will try to bid on the price of the goods or services, so that there is a bargain between the two parties. After an agreement is made, a price is formed. The market as a means of promotion means that the market is a place to introduce and inform a good / service about its benefits, advantages, and uniqueness to consumers. Promotion is carried out to attract buyers to the introduced goods or services.

\section{b) Buying and Selling Behavior}

Humans are social creatures who need interaction. By interacting, they can benefit and benefit. One of the practices that is the result of human interaction is the occurrence of buying and selling in which they are able to get the needs they want. Islam also regulates this problem in detail and thoroughly so that when entering into buying and selling transactions, humans are able to interact in the corridor of sharia and avoid acts of persecution against fellow humans, this shows that Islam is a universal and comprehensive teaching.

In buying and selling there are benefits and social urgency, if it is forbidden it will cause various losses. Based on this, all transactions (buying and selling) carried out by legal persons are legally lawful, unless there are arguments that prohibit the transaction. Prohibited buying and selling according to Islam is buying and selling containing usury, haram goods, reducing the scale and by force.

\section{c) Money}

When Islam came, the economic transaction system and activities that were already in effect in the midst of society using money that were already in circulation were recognized by the Prophet SAW. He acknowledged the money as legal money. Islamic money or also known as the Islamic Dinar was only made at a later date. According to historians, the person who first issued Dirhams and Dinars to be enforced in an Islamic country was the Caliph Bani Umayah Abdul Malik bin Marwan in $74 \mathrm{AH}$

When the Umayyad government was established, money-making still followed in the footsteps of its predecessors, namely enforcing Sasani and Byzantine currency by affixing several Islamic symbols, such as the name of the caliph, and leaving non-Islamic symbols on the money. In the early days of this government money making was not the authority of any particular party in government. Apart from the caliph, the governors and leaders in the regions also made special money for their respective regions. Islamic money or also known as the Islamic Dinar was only made during the time of the Caliph Bani Umayah Abdul Malik bin Marwan in 74 $\mathrm{AH}$.

\section{CONCLUSION}

The Arabs of the ignorance era had a market as a trading center as well as a meeting point for literary experts, poets and orators. Riba is a type of economic transaction that is actually carried out and developed in Arab society. Transactions of this type have existed since before Islam, a period which in the historical perspective of Islam is known as the period of ignorance. In making transactions using existing money, both gold dinars and silver dirhams, it is based on the scales, not on the number, because the money is not the same in weight. 
In Islam, the market is guaranteed freedom. as a means of distribution, a meeting place between sellers and buyers as well as a place to introduce and inform a good / service. In buying and selling there are benefits and social urgency. Buying and selling is prohibited according to Islam when it contains usury, haram goods, reducing the scale, and by force.

\section{REFERENCES}

Chamid, N. (2010). Jejak Langkah Sejarah Pemikiran Ekonomi Islam. Pustaka Pelajar.

Departemen Agama Republik Indonesia. (1984). Al-Quran dan Terjemahnya. Yayasan Penyelenggara Penterjemah Al-Qur'an.

Djunaedi, W. (2008). Fiqih. PT. Listafariska Putra.

Hasan, M. A. (2004). Berbagai Macam Transaksi Dalam Islam Fiqh Muamalah. PT Raja Grafindo Persada.

Ihsan, G. (2008). Fiqh Muamalat. Prenada Media Grup.

Nasrun, H. (2007). Fiqh Muamalah. Gaya Media Pratama.

Nawawi, S., \& Zayadi, A. (1994). Petunjuk Praktis Menulis Karya Ilmiah. KMI Gontor.

Suhendi, H. (2002). Fiqh Muamalah. PT Raja Grafindo Persada.

Tarmizi, E. (2014). Harta Haram Muamalat Kontemporer. PT. Berkat Mulia Insani.

Zulhaily, W. (1999). Fiqh Muamalah Perbankan Syariah Al-Fiqhu Islam Wa Adillatuhu. Kapita Selekta.

Zulhaily, W. (2005). Al-Figh al-Islami wa Adillatuh (Vol. 4). 